\title{
HOW PRIOR KNOWLEDGE, PROSPECT, AND LEARNING BEHAVIOUR DETERMINE LEARNING OUTCOMES OF BIPA STUDENTS?
}

\author{
Imam Suyitno*, Yuni Pratiwi, Roekhan, Martutik \\ Universitas Negeri Malang, Indonesia \\ *e-mail: imam.suyitno.fs@um.ac.id
}

\begin{abstract}
Many learning theories explain that prior knowledge, prospects, and learning behavior affect student learning outcomes. Related with these theories, this study aimed to describe these three variables for graduate students and their correlation in learning in the BIPA elective program (Bahasa Indonesia untuk Penutur Asing/Indonesian Language for Native Speakers). In addition, this study also described the implications of these three variables on student learning outcomes. Therefore, this study used a quantitative approach involving 17 graduate students who choose BIPA specialization programs. Data about the prospects and learning behavior were collected using a questionnaire, while the student's prior knowledge data was collected using a test instrument that contained general knowledge about BIPA. Meanwhile, student learning outcomes were obtained from student achievement index modified to a standard score. Data analysis used multiple correlation techniques. The findings of the study indicate that the prior knowledge of students about $B I P A$ is in a low category, their prospects and learning behavior are in the high category, and the achievement index shows that their learning outcomes are in the very high category. Student prior knowledge does not correlate with prospects and learning behavior, whereas student learning behavior correlates with their prospects. Simultaneously, the three variables do not correlate with their learning outcomes.
\end{abstract}

Keywords: prospect, prior knowledge, learning behavior, learning outcomes

\section{BAGAIMANA PENGETAHUAN AWAL, PROSPEK, DAN PERILAKU BELAJAR, MENENTUKAN HASIL BELAJAR MAHASISWA BIPA?}

\begin{abstract}
Abstrak: Banyak teori belajar menjelaskan bahwa ada berbagai faktor yang memengaruhi hasil belajar siswa, di antaranya adalah pengetahuan awal, prospek, dan perilaku belajar. Sejalan dengan teori-teori ini, penelitian ini bertujuan mendeskripsikan pengetahuan awal, prospek, dan perilaku belajar mahasiswa pascasarjana, serta korelasi ketiga variable tersebut dalam pembelajaran pada program pilihan BIPA (Bahasa Indonesia untuk Penutur Asing). Selain itu, kajian ini juga mendeskripsikan implikasi ketiga variable tersebut pada hasil belajar mahasiswa. Karena itu, penelitian ini menggunakan pendekatan kuantitatif yang melibatkan 17 mahasiswa pascasarjana yang memilih program spesialisasi BIPA. Data tentang prospek dan perilaku belajar dikumpulkan dengan menggunakan kuesioner, sedangkan data pengetahuan awal mahasiswa dikumpulkan dengan menggunakan instrumen tes yang berisi pengetahuan umum tentang BIPA. Sementara, hasil belajar mahasiswa diperoleh dari dokumen indeks prestasi mahasiswa yang dimodifikasi ke skor standar. Analisis data menggunakan teknik korelasi ganda. Temuan kajian tersebut menunjukkan bahwa pengetahuan awal mahasiswa tentang BIPA termasuk kategori rendah, prospek dan perilaku belajar mereka termasuk kategori tinggi, dan indeks prestasi yang menunjukkan hasil belajar mereka termasuk kategori sangat tinggi. Pengetahuan awal mahasiswa tidak berkorelasi dengan prospek dan perilaku belajar, sedangkan perilaku belajar mahasiswa berkorelasi terhadap prospek mereka. Secara simultan, ketiga variabel tersebut tidak berkorelasi dengan hasil belajar mereka.
\end{abstract}

\section{Kata Kunci: prospek, pengetahuan awal, perilaku belajar, hasil belajar}

\section{INTRODUCTION}

Prior knowledge is the knowledge that students already have before they get new information in the activities that will be carried out. A student at the beginning of learning at a higher academic level has prior knowledge gained from previous education. Prior knowledge is an initial experience that underlies the students' understanding to make decisions in determining their learning choices. When will determine their learning choices, students activate their prior knowledge and based on that 
knowledge students develop their experience in the chosen training.

Prior knowledge is a positive energy that builds an impression on students so that it encourages them to have the prospect of learning. The findings of previous studies that investigated the effects of students intrinsic motivation and prior knowledge on Chinese learning achievement showed that students' prior knowledge and intrinsic motivation influenced their achievement in learning Chinese. Previous knowledge possessed by students also has an influence on students' intrinsic motivation (Baek, Xu, Han, \& Cho, 2015).

In achieving the expected goals, individuals generally control themselves by evaluating themselves based on their prior knowledge. The evaluation is related to the strategies carried out and the learning outcomes that have been achieved. The results of these evaluations are useful as feedback to improve their learning strategies (Snyder, Shorey, Cheavens, Pulvers, Adams, \& Wiklund, 2002). Self-evaluation is useful for various purposes and help individuals or entities in reflecting their performance to measure strengths and weaknesses in work (McNamara \& O'Hara, 2008)

Postgraduate students are adult students who have diverse prior knowledge so that they have different motivations, prospect, and privacy in learning. Maturity brings unique characteristics that influence the way they are motivated to learn (Malamed, 2009). Adult students can control themselves and think carefully to determine the choice of activities they will do. By the learning, they expect to have added value that is useful for their future.

Mindset and learning orientation of postgraduate students are different from undergraduate students. In the learning process, they always direct their learning activities to discover new knowledge, skills, and experiences needed for their life. This condition implies the learning process. Lecturers need to consider selfconcept, the role of experience, learning readiness, and learning orientation of their students. It is necessary to regulate the physical environment, social and psychological environment, diagnosis of learning needs, careful planning, clear learning goals, participatory learning models, learning materials and techniques tailored to students' experiences.
Every student in conducting learning activities has a prospect. Prospect is a distant view of what must be done in learning to achieve future goals. The prospect is normative and abstract so that it cannot be stated concretely because it explains about the detailed description of desires expected by individuals personally. However, several aspects can be explored from this prospect, including (a) future orientation, (b) aspired targets, and (c) principles of values that contain rewards (Sora, 2014). Prospect in learning can be said as orientation, target, and values aspired by students for their future that are realized through learning activities.

Prospect in learning is one of the factors that form the expectation of success in learning. The expectation of success in learning is a thought that contains agency, effort, and method (pathway), and individual assessment of the chances of success of the study (Snyder, Rand, $\&$ Sigmon, 2002). The prospect is an important factor that encourages students to be more active in fighting for the hope of success. Students' expectations for success will encourage them to study hard in achieving the expected goals. Students who have future expectation will learn well to complete their learning tasks (Jembarwati, 2015).

Students who have prospects will do learning activities programmatically. The strong and weak orientation to the future will be seen in the quality of their learning behavior. They always act in a planned manner and believe that the learning strategies they do can achieve their goals. Such activities will continue to encourage them to act actively in achieving their learning goals (Snyder, 2010). Students who have a prospect will have good learning behavior because they have programmed planning and learning strategies.

In realizing prospects, students prefer to take the education process rather than doing other activities. Learning orientation for the sake of the future is a locus of internal control for their goals and expectations. The prospect is the expectation of the ideal that can be achieved for the future of his life. The students' prospect is to guide behavior as well as motivation in learning to achieve future success. In this case, futureoriented learning will direct behavior to meet needs in achieving goals, plans that have been prepared, and hopes that are aspired (Seginer, 
2009). Such behavior is carried out to overcome difficulties in maintaining future expectations (Leonard \& Amanah, 2017). Future-oriented students will be motivated to achieve the desired goals and continue to obtain an optimal learning experience.

Based on the descriptions above, this article presents the findings of quantitative research that described students' prior knowledge, prospects, and learning behaviour, and its correlation in BIPA elective program. The study also sought to know the implication of students' prior knowledge, prospects, and learning behaviour on their learning outcomes in the chosen BIPA elective program. The findings of this study have significant benefits for students, lecturers, and further research. For the students, these findings can be feedback to improve their learning performance and optimize their achievement. For lecturers, the findings provide useful information for designing lecture assignments that can motivate and challenge students to generate student performance in achieving their expectations. Meanwhile, for further researchers, the findings of this study can be a reference in developing a research design, preparing theoretical frameworks, determining samples and data, and analyzing data.

\section{METHOD}

This study used a quantitative approach. Participants of the study were 17 postgraduate students who chose the BIPA program specification. They were semester 2 students who have taken several general courses, but have not taken BIPA specification courses. They took $B I P A$ specifications starting from semester 2 .

To answer the problem of the study, the data collected in this study were in the form of quantitative data, namely scores about previous knowledge, prospects, learning performance, and grade point indexes achieved by students. To obtain data on prior knowledge, this study used a test instrument about BIPA knowledge, which is a multiple choice test consisting of 50 items. Meanwhile, to obtain data on prospects and learning performance, this study used a closed questionnaire, each of which consisted of 20 questions (a test instrument questionnaire and a questionnaire can be seen in the appendix).
Meanwhile, to obtain data about student learning outcomes, the study conducted a document study of grade point index achieved by students in the transcript of their study results.

To gain an understanding of prior knowledge of students, their prospects in taking the BIPA specification program, and their learning behavior in lectures, this study conducted descriptive statistical calculations using the statistical application of SPSS version 20. Through descriptive calculations, the results of calculations can be obtained on average score (mean), median (median), and frequently occurring values (mode). Meanwhile, to find out the findings about the correlation between the three variables and their implications for learning outcomes, this study applies a multiple regression analysis, which is to measure the relationship of an independent variable (prior knowledge, prospects, and learning performance) with an independent variable (learning outcomes). The use of multiple correlation techniques is intended to show the direction and strength of the relationship between the three independent variables partially and simultaneously with one dependent variable. In this case, the relationship between prior knowledge, prospects, and student learning behavior with student learning outcomes.

\section{FINDINGS AND DISCUSSION \\ Findings}

The Descriptions of Prior Knowledge, Prospect, Learning Behaviour, and Learning Outcome of Postgraduate Students in BIPA Elective Program

Based on the analysis results, the average score of students' prior knowledge is 47.01, students' prospect is 78.97, students' learning behaviour is 75.51, and students' learning outcome is 95.57. Based on the score, it can be concluded that prior knowledge of students is in low category, whereas students' prospect and learning behaviour are in high category. Meanwhile, their learning outcome is in very high category.

The correlation between students' prior knowledge, students' prospect, and students' prospects in BIPA elective learning can be seen in Table 1-3. 
Table 1. Correlations between Students' Prior Knowledge and Their Prospects

\begin{tabular}{llcc}
\hline & & Prior Knowledge & Prospect \\
\hline Prior & Pearson Correlation & 1 & .191 \\
& Sig. (2-tailed) & & .462 \\
& Sum of Squares and Cross-products & 920.941 & 278.529 \\
& Covariance & 57.559 & 17.408 \\
& N & 17 & 17 \\
& Pearson Correlation & .191 & 1 \\
& Sig. (2-tailed) & .462 & \\
& Sum of Squares and Cross-products & 278.529 & 2300.735 \\
& Covariance & 17.408 & 143.796 \\
& N & 17 & 17 \\
\hline
\end{tabular}

Based on the table above, it can be seen that the level of significance of the correlation between students' prior knowledge and their prospect is $.462(>.05)$. This shows that there is no significant correlation between students' prior knowledge and their prospect in the BIPA elective program. Based on the magnitude of the significance level, it can be said that the high and low prior knowledge of students does not always correlate with their high and low prospects in $B I P A$ elective program.

The results of the correlation analysis between students' prospect and their learning behaviour can be seen in the Table 2 .
It can be seen that the significance level of the correlation between students' prospect and their learning behaviour is $.013(<.05)$. From this significance level, it can be said that students 'prospects correlate significantly with students' learning behaviour. This shows that the higher the prospect of students will be the stronger their learning behaviour.

The results of SPSS analysis shows that the correlation between students' prior knowledge and their learning behavior in BIPA elective learning can be seen in Table 3 .

The results of the SPSS analysis in the table above show that the significance level of the

Table 2. Correlations between Students' Prospect and Their Learning Behavior

\begin{tabular}{llcc}
\hline & & Prospect & Learning Behavior \\
\hline Prospect & Pearson Correlation & 1 & $.590^{*}$ \\
& Sig. (2-tailed) & & .013 \\
& Sum of Squares and Cross-products & 2300.735 & 1423.070 \\
& Covariance & 143.796 & 88.942 \\
Behavior & 17 & 17 \\
& Pearson Correlation & $.590^{*}$ & 1 \\
& Sig. (2-tailed) & .013 & \\
& Sum of Squares and Cross-products & 1423.070 & 2531.434 \\
& Covariance & 88.942 & 158.215 \\
& N & 17 & 17 \\
\hline
\end{tabular}


Table 3. Correlations between Students' Prior Knowledge and Their Learning Behaviour

\begin{tabular}{llcc}
\hline & & Prior & Behavior \\
\hline Prior & Pearson Correlation & 1 & -.014 \\
& Sig. (2-tailed) & & .957 \\
& Sum of Squares and Cross-products & 920.941 & -21.765 \\
& Covariance & 57.559 & -1.360 \\
& $\mathrm{~N}$ & 17 & 17 \\
Behavior & Pearson Correlation & -.014 & 1 \\
& Sig. (2-tailed) & .957 & \\
& Sum of Squares and Cross-products & -21.765 & 2531.434 \\
& Covariance & -1.360 & 158.215 \\
& $\mathrm{~N}$ & 17 & 17 \\
\hline
\end{tabular}

correlation between students' prior knowledge and their learning behaviour is .957 (> .05). The level of significance indicates that students' prior knowledge and their learning behaviour do not correlate significantly. The high and low level of students' prior knowledge does not always correlate with strong and weak student learning behaviour.

The Implications of Students' Prior Knowledge, Prospects, and Learning Behaviour to Their Learning Outcome in BIPA Elective Program

The results of the SPSS analysis inform that implication of students' prior knowledge, prospects, and learning behavior to their learning outcomes can be seen in the Table 4 .
From the results of the analysis above, it can be seen that the predictor significance level in the dependent variable is .893 (>.05). This shows that students "prior knowledge, prospects, and learning behavior do not have a significant influence on the students' learning outcomes. This means that simultaneous highlevel students' prior knowledge, prospects, and learning behavior do not always have implications for the high level of their learning outcomes in BIPA elective programs.

If analyzed partially, from the three predictor variables, the variables that have the greatest implications for the learning outcome are shown in the Table 5.

Table 4. Implication of Students' Prior Knowledge, Prospects, and Learning Behavior to Their Learning Outcomes

\begin{tabular}{llccccc}
\hline & Model & Sum of Squares & df & Mean Square & F & Sig. \\
\hline 1 & Regression & 1.759 & 3 & .586 & .202 & $.893^{\mathrm{a}}$ \\
& Residual & 37.711 & 13 & 2.901 & & \\
\cline { 2 - 5 } & Total & 39.471 & 16 & & & \\
\hline
\end{tabular}

a. Predictors: (Constant), Behavior, Prior, Prospect

b. Dependent Variable: GPI 
Table 5. Partial Correlation Coefficients ${ }^{a}$

\begin{tabular}{|c|c|c|c|c|c|c|c|c|c|c|c|c|c|}
\hline \multirow{2}{*}{\multicolumn{2}{|c|}{ Model }} & \multicolumn{2}{|c|}{$\begin{array}{l}\text { Unstandardized } \\
\text { Coefficients }\end{array}$} & \multirow{2}{*}{$\begin{array}{c}\begin{array}{c}\text { Standardized } \\
\text { Coefficients }\end{array} \\
\text { Beta }\end{array}$} & \multirow{2}{*}{$\mathbf{t}$} & \multirow{2}{*}{ Sig. } & \multicolumn{2}{|c|}{$\begin{array}{l}\text { 95\% Confidence } \\
\text { Interval for B }\end{array}$} & \multicolumn{3}{|c|}{ Correlations } & \multicolumn{2}{|c|}{$\begin{array}{c}\text { Collinearity } \\
\text { Statistics }\end{array}$} \\
\hline & & B & $\begin{array}{l}\text { Std. } \\
\text { Error }\end{array}$ & & & & $\begin{array}{l}\text { Lower } \\
\text { Bound }\end{array}$ & $\begin{array}{l}\text { Upper } \\
\text { Bound }\end{array}$ & $\begin{array}{l}\text { Zero- } \\
\text { order }\end{array}$ & Partial & Part & $\begin{array}{l}\text { Tole- } \\
\text { rance }\end{array}$ & VIF \\
\hline \multirow[t]{4}{*}{1} & (Constant) & 93.173 & 3.850 & & 24.200 & .000 & 84.855 & 101.491 & & & & & \\
\hline & Prior & .005 & .058 & .026 & .093 & .928 & -.120 & .131 & .064 & .026 & .025 & .939 & 1.065 \\
\hline & Prospect & .026 & .045 & .199 & .575 & .575 & -.072 & .124 & .210 & .157 & .156 & .612 & 1.633 \\
\hline & Behavior & .001 & .042 & .009 & .028 & .978 & -.091 & .093 & .126 & .008 & .008 & .636 & 1.574 \\
\hline & Dependent V & Jariable: $\mathrm{C}$ & & & & & & & & & & & \\
\hline
\end{tabular}

Partially predictor variables do not have a significant contribution to learning outcomes. The significance level of the contribution is as follows: (a) prior knowledge on learning outcomes is .928 ( $>.05)$, (b) prospects on learning outcomes are $.575(>.05)$, and (c) learning behaviour on learning outcomes is $.978(>.05)$. Based on the magnitude of the significance level of each of these variables, it can be said that prior knowledge, prospect, and learning behaviour contribute insignificantly to learning outcomes. Although not significant, the magnitude of the contribution of each variable can be compared. The highest contribution of the three variables is the prospect (.157), while prior knowledge has a contribution of .026 and learning behaviour has a contribution of .008 .

\section{Discussion \\ Prior Knowledge, Prospect, and Learning Behaviour of Postgraduate Students in BIPA Elective Program}

Based on the findings of the study, it can be said that students do not understand BIPA learning adequately. This happened because the students had never studied the BIPA material so they did not have enough knowledge about BIPA. Prior knowledge is the condition of knowledge possessed by students before they acquire knowledge of further learning assignments. Understanding prior knowledge of students is important because it is the key to learning (Barrette \& Paesani, 2018). Such knowledge is an important factor because it can affect the process and results of subsequent lectures (Newman, Trimmer, \& Padró, 2019). This understanding of prior knowledge is important for both students and lecturers because it can be a controlling factor in the implementation of learning.
The findings also showed that students have high prospects in the BIPA elective program. Prospect is a series of words that show dreams, ideas or core values that are owned by a person or organization. Prospect is also thoughts that are in someone's mind. These thoughts are a picture of the future to be achieved. A prospect is a possibility that something fabulous will happen. Prospect in learning can be interpreted as a foresight regarding the direction of selfmanagement in learning, namely what will be done in learning to build success for the future (Salamadian, 2017).

A students' prospect in learning is built on two factors, namely their ideology and future expectations. Both of these factors build individual perceptions and behavior in their interactions with their learning environment. The behavior of each learning varies because each has a different perception. Characteristics possessed by individuals will be taken when the individual enters a new learning task (Nurmaleny, 2014).

Based on the findings, it can be known that students have a good learning behaviour in the BIPA elective program. Student learning behavior reflects the personality possessed by students. Their personality developed based on environmental situations that affect them. Burk (2015) said that the environment can be positive or negative, but from that environment allows them to grow and develop. Kusaeri, Aditomo, Ridho, \& Fuad (2018) revealed that student learning behavior is influenced by various factors, including family background, habits in the social environment, and prior learning experiences. In this case, personality is the beliefs, behaviors, and values that form the main characteristics of an individual. Students' personality determines the way they interact with their environment 
and react in certain situations. The results of the study have important significance for the development of learning programs, especially in efforts to improve learning program services for students. By quoting a statement said by Hastuti, Alfiasari, Hernawati, Oktriyanto, \& Puspitasari (2019), it can be revealed that in order to develop programs that can improve the quality of learning outcomes, it is necessary to examine to provide an empirical framework as a basis for program development.

Learning Behavior emphasizes the important relationship between the way students learn and their social knowledge and behavior. In carrying out these activities, the focus is on building positive relationships between three, namely the elements of self, others and curriculum. Sitorus, Siswandari, \& Kristiani (2019) studied that learning behavior has a positive correlation with learning outcomes achieved by students. The principles of student learning behavior have broad implications for students, lecturers, and other professionals. Learning behavior is everything that is done by students to achieve the goals of their learning. Learning behavior between one student with one another varies because they have different characteristics (Naomi, 2007). Learning behavior can be said as learning activities performed by students in completing learning tasks (Chance, 2013).

Based on the description of the results of the analysis above, it can be stated that prior knowledge does not correlate significantly with the prospect. This shows that students who have high prior knowledge must not have prospects that are following their knowledge. Student prospects are likely to change due to changes in thinking based on the new situation at hand. The new environment faced by students is likely to be more challenging and more interesting so that it significantly influences students' minds to change their prospects. Academic social environment influences and changes the life principle of students to determine their future expectations. These findings are in line with a psychological theory which explains that a person's personality is influenced and shaped by the surrounding environment (John, Robins, \& Pervin, 2008).

The absence of a relationship between prior knowledge with the prospects of students needs to be a concern for program managers. Program managers must be proactive in finding solutions to minimize the potential for discrepancies between what the institution expects and what they expect (Hassel \& Ridout, 2018). This problem tends to become increasingly important considering that their success is not only determined by their previous competence but also determined by other factors outside the student. The difference between what students think or what they expect in learning has a significant effect on their academic preparedness.

The findings of this study also show that prior knowledge correlates not significantly with learning behavior. These findings indicate that students' social-academic maturity is more determined by their academic social environment. The results of other previous studies that examined genetic, cross-cultural, and prospective-longitudinal behavior showed that genetic influences undoubtedly played an important role, but the influence of the environment on personality development became more important and more stable during the early adult period. The transition of social roles is related to personality-character changes towards greater social maturity (Bleidorn, 2015).

The findings of this study indicate that there is a correlation between prior knowledge and learning behavior even though the correlation has a low significance. This is another problem that concerns their expectations about how they will get study services at the university (Senior, Fung, Howard, \& Senior, 2018). The findings show that students have learning preferences in small classes, compared to learning in large classes (Borghi, Mainardes, \& Silva, 2016). Through small classes, students have greater opportunities for face-to-face interaction with teaching staff (Money, Nixon, Tracy, Hennessy, Ball, \& Dinning, 2017). Their dependence on obtaining maximum services from teachers they can get because they are in the teaching of small classes.

The description above shows that the environment affects one's personality as reflected in future expectations and behavior in their lives. This study adds a proof that the prospects of students have a significant correlation with their learning behavior. Based on the findings of this study, it can be concluded that the students' personality controls their 
prospects and behavior. Student learning behavior is understood as a mental process that changes their perception to choose an action that is considered most appropriate for their future. This behavior includes all types of behavior in decision making that are intuitive, automatic, impulsive, and deliberate decision making (Van de Kaa, 2010). Differences in student character and the impact of decision-making distinguish their strategic, tactical and operational choices in learning.

\section{The Implication of Prior Knowledge, Prospect, and Learning Behaviour to Learning Outcome}

The results of this study show that prior knowledge, prospects, and student learning behavior, both partially and simultaneously, do not significantly influence student learning outcomes. These findings appear different from learning theories in general. In learning theory, explained the ways and processes of students in absorbing, processing, and maintaining knowledge during learning. The influence of cognitive, emotional, and environmental, as well as previous experience influences the way of understanding, looking at the future, gaining knowledge, and maintaining the skills that have been acquired (Schunk, 2011). Therefore, the findings of this study are not in line with the learning theory. The differences can be explained from various aspects, namely the aspects of the instruments used for collecting data, student characteristics, and student learning outcomes.

Instruments for measuring prior knowledge of students are developed based on the subject matter specifically related to learning Indonesian for foreign students. Meanwhile, learning outcomes used as a reference to determine the success of student studies are grade point indexes obtained by students in the previous semester. The grade point index is the average value of accumulated values for several courses for the master degree program that are more theoretical and general. Therefore, it can be understood that there is no contribution of prior knowledge to these learning outcomes because the questions used to measure prior knowledge are only a small part of general knowledge that should be included in the course. Norman, Blakstad, Johnsen, Martinsen, \& Price (2016) examine the relationship of specific questions to general knowledge. The results of their study explained that specific questions were not suitable for measuring students' general knowledge.

Students have different preferences related to how they learn. Learning strategies that must be normatively carried out by students are probably not following the way of learning adult students who already have various learning style references (Mkonto, 2015). They generally have chosen and determined their learning style so that the learning styles and strategies asked in the questionnaire are deemed not according to their preferences. Therefore, the findings of this study indicate that student learning behavior does not contribute significantly to their learning outcomes. There are obviously many other factors could have interacted with the learning outcomes, which is worthed it to be investigated in the future.

\section{CONCLUSION}

It can be concluded that students did not have sufficient knowledge about BIPA learning because this knowledge is new material for them. Their lack of knowledge about BIPA does not correlate with their prospects and learning behavior. The high prospects and their behavior in learning is largely determined by the learning environment that makes them eager to learn. This learning environment is what drives them to achieve very high learning outcomes.

These findings have important meaning for higher education institutions, especially for teaching staff and managers of learning programs. However, behind these findings, there may still be bias so that the findings cannot be fully used as guidelines for changing the learning program. This study has limitations, especially concerning too few sample sizes. The small number of samples is likely to cause bias in the results of statistical analysis. The finding bias is also likely to occur because of the use of non-standard measuring instruments, namely predicting general learning outcomes by using specific questions. Therefore, these limitations can be an important concern for future researchers so that in developing their study designs, they can determine larger samples and more careful in the preparation of their research instruments. 


\section{REFERENCES}

Baek, Y., Xu, Y., Han, S., \& Cho, J. (2015). Exploring effects of intrinsic motivation and prior knowledge on student achievements in game-based learning. The Smart Computing Review, 5(5), 368377. doi:10.6029/smartcr.2015.10.001.

Barrette, C. M., \& Paesani, K. (2018). Conceptualizing cultural literacy through student learning outcomes assessment. Foreign Language Annals, 51(2), 331343. doi:10.1111/flan.12337.

Bleidorn, W. (2015). What accounts for personality maturation in early adulthood? Current Directions in Psychological Science, 24(3), 245-252. doi:10.1177/0963721414568662.

Borghi, S., Mainardes, E., \& Silva, É. (2016). Expectations of higher education students: A comparison between the perception of student and teachers. Tertiary Education and Management, 22(2), 171-188. doi:10. 1080/13583883.2016.1188326.

Burk, S. (2015, April 30). Role of environment in personality development. Retrieved from https://prezi.com/.

Chance, P. (2013). Learning and behavior ( $^{\text {th }}$ ed). Belmont, CA: Cengage Learning.

Hassel, S., \& Ridout, N. (2018). An investigation of first-year students' and lecturers' expectations of university education. Frontiers in Psychology, 8(2218), 1-13. doi:10.3389/fpsyg.2017.02218.

Hastuti, D., Alfiasari, A., Hernawati, N., Oktriyanto, O., \& Puspitasari, M. D. (2019). Effectiveness of "Pik-R" program as an extracurricular for high/vocational school students in preventing negative behaviors of adolescents. Cakrawala Pendidikan, 38(1), 1-15. doi:10.21831/ cp.v38i1.22283.

Jembarwati, O. (2015). Pelatihan orientasi masa depan dan harapan keberhasilan studi pada siswa SMA. Humanitas, 12(1), 4551. doi:10.26555/humanitas.v12i1.3828.

John, O. P., Robins, R. W., \& Pervin, L. A. (2008). Handbook of personality: Theory and research $\left(3^{\text {rd }} \mathrm{ed}\right)$. New York, NY: The Guilford Press.

Kusaeri, K., Aditomo, A., Ridho, A., \& Fuad, A. Z. (2018). Socioeconomic status, parental involvement in learning and student' mathematics achievement in Indonesian Senior High School. Cakrawala Pendidikan, 37(3), 333-344. doi:10.21831/cp.v38i3.21100.

Leonard, L., \& Amanah, N. (2017). Pengaruh adversity quotient dan kemampuan berpikir kritis terhadap prestasi belajar matematika. Perspektif Ilmu Pendidikan, 28(1), 55-64.

Malamed, C. (2009). Characteristics of adult learners. Retrieved from http:// theelearningcoach.com/.

McNamara, G., \& O'Hara, J. (2008). The importance of the concept of selfevaluation in the changing landscape of education policy. Studies in Educational Evaluation,34(3), 173-179. doi:10.1016/j. stueduc.2008.08.001.

Mkonto, N. (2015). Students' learning preferences. Journal of Studies in Education, 5(3), 212-235. doi:10.5296/ jse.v5i3.8125.

Money, J., Nixon, S., Tracy, F., Hennessy, C., Ball, E., \& Dinning, T. (2017). Undergraduate student expectations of university in the United Kingdom: What really matters to them? Cogent Education, 4(1), 1-11. doi:1 0.1080/2331186X.2017.1301855.

Naomi, M. R. W. P. (2007). Pengaruh motivasi diri terhadap kinerja belajar mahasiwa studi kasus pada mahasiswa Universitas Paramadina. Abmas, 7(7), 1-8.

Newman, T., Trimmer, K., \& Padró, F. F. (2019). The need for case studies to illustrate 
quality practice: Teaching in higher education to ensure quality of entry level professionals. In K. Trimmer, T. Newman, \& F. F. Padró (Eds.), Ensuring quality in professional education Volume I: Human client fields pedagogy and knowledge structures (pp. 1-17). Switzerland, AG: Palgrave Macmillan. doi:10.1007/978-3030-01096-6 1.

Norman, E., Blakstad, O., Johnsen, Ø., Martinsen, S. K., \& Price, M. C. (2016). The Relationship between feelingsof-knowing and partial knowledge for general knowledge questions. Frontiers in Psychology, 7, 1-7. doi:10.3389/ fpsyg.2016.00996.

Nurmaleny, F. (2014). Faktor pembentuk persepsi mahasiswa pendidikan akuntansi angkatan 2011 dan 2012 dalam memilih bidang keahlian khusus pendidikan akuntansi Fakultas Keguruan dan Ilmu Pendidikan Universitas Sebelas Maret (Undergraduate Thesis, Universitas Sebelas Maret). Retrieved from https:// digilib.uns.ac.id/.

Salamadian, S. (2017, August 30). Visi dan misi: Pengertian, contoh \& perbedaan visi dan misi. Retrieved from https://salamadian. com/.

Schunk, D. H. (2011). Learning theories: an educational perspective ( $6^{\text {th }}$ ed). Boston, MA: Pearson.

Seginer, R. (2009). Future orientation: Developmental and ecological perspectives. New York, NY: Springer Science + Business Media. doi:10.1007/ b106810.
Senior, C., Fung, D., Howard, C., \& Senior, R. (2018). Editorial: What is the role for effective pedagogy in contemporary higher education? Front. Psychol, 9, 1-3. doi:10.3389/fpsyg.2018.01299.

Sitorus, D. S., Siswandari, S., \& Kristiani, K. (2019). The effectiveness of accounting e-module integrated with character value to improve students' learning outcomes and honesty. Cakrawala Pendidikan, 38(1), 120-129. doi:10.21831/cp.v38i1.20878.

Snyder, C. R. (2010). Psychology of hope: You can get here from there. Riverside, CA: Free Press.

Snyder, C. R., Rand, K. L., \& Sigmon, D. R. (2002). Hope theory: A member of the positive psychology family. In C. R. Snyder \& S. J. Lopez (Eds.), Handbook of Positive psychology (pp. 257-276). New York, NY: Oxford University Press.

Snyder, C. R., Shorey, H. S., Cheavens, J., Pulvers, K. M., Adams III, V. H., \& Wiklund, C. (2002). Hope and academic success in college. Journal of Educational Psychology, 94(4), 820-826. doi:10.1037/0022-0663.94.4.820.

Sora N. (2014, September 26). Pengertian visi dan misi beserta perbedaannya. Retrieved from https://www.pengertianku.net/.

Van de Kaa, E. J. (2010). Prospect theory and choice behaviour strategies: Review and synthesis of concepts from social and transport sciences. European Journal of Transport and Infrastructure Research (EJTIR), 10(4), 299-329. doi:10.18757/ ejtir.2010.10.4.2897. 


\section{APPENDIX}

\section{Appendix 1. Outline of Test Materials}

$\begin{array}{cc}\text { Components } & \text { Sum of } \\ \text { Indem Test }\end{array}$

Indonesian as a foreign language Nature, position, functions, problems, and prospects of BIPA 10

Cross-cultural understanding Concepts of culture, the scope of cross-cultural studies, 10 cultural values, cultural behavior

Learning program Characteristics of the BIPA program, components of the BIPA program, techniques and procedures for developing the $B I P A$ program

Teaching materials development Learning resources and BIPA teaching materials, types and criteria for selecting $B I P A$ teaching resources and materials, techniques and procedures for developing $B I P A$ teaching materials

Developing learning strategies The approach, method, strategy for BIPA learning technique, various $B I P A$ learning strategies, implementation of $B I P A$ learning

\begin{tabular}{lc}
\hline Total & 50
\end{tabular}

\section{Appendix 2. Questionnaire of Students' Prospect in Learning}

\begin{tabular}{llllll}
\hline No. Statements & Choice Answer \\
\cline { 2 - 5 } & 1 & 2 & 3 & 4
\end{tabular}

1 You know BIPA correctly and adequately.

2 You have complete prospect into the future of the BIPA program

3 You know the importance of the BIPA program for now or for the future

4 You predict that the BIPA program will continue to grow both domestically and abroad

5 You have an idea that the BIPA program will provide employment opportunities for you

6 You have a prediction that after graduating later you will immediately get a job to teach $B I P A$

7 You have an idea that after graduation, you will become a master who is an expert in $B I P A$

8 You have an idea that after graduation, you will become a BIPA developer and researcher

9 You have an idea that after graduation, you will become a reliable BIPA teacher

10 You have aspirations to contribute your experience in the internationalization of Indonesian language through BIPA learning

11 You choose the interest of BIPA because it is under the expectations of expertise for your future

12 You choose the interest of BIPA because you want to deepen your knowledge about BIPA

13 You choose the interest of BIPA because you have realized the importance of BIPA learning

14 You choose BIPA specialization because it is under the basic abilities that you have

15 You choose BIPA interest because you feel that the class is the most suitable for you

16 You understand the prospect and mission of the BIPA specialization program

17 You understand the long-term goals that are expected from the opening of the BIPA specialization program

18 You know the contents of the lecture as a learning experience that you will get in lectures

19 You understand the path of collaboration to develop the learning experience that you can get after graduating

20 You already have a partnership with certain institutions that can accommodate your experience and expertise in the field of $B I P A$ 


\section{Appendix 3. Questionnaire of Learning Performance Quality}

\begin{tabular}{|c|c|c|c|c|c|}
\hline \multirow{2}{*}{ No. } & \multirow{2}{*}{ Statements } & \multicolumn{4}{|c|}{ Choice Answer } \\
\hline & & 1 & 2 & 3 & 4 \\
\hline 1 & You always try to find yourself new experiences about $B I P A$ that support your ideas & & & & \\
\hline 2 & $\begin{array}{l}\text { You always study and look at the syllabus that has been given to you before the } \\
\text { lecture is held }\end{array}$ & & & & \\
\hline 3 & $\begin{array}{l}\text { You always try to find and collect books that are obligatory or support that is } \\
\text { suggested in the syllabus before the lecture is held }\end{array}$ & & & & \\
\hline 4 & You are always ready with the material that will be discussed in the lecture & & & & \\
\hline 5 & $\begin{array}{l}\text { You always prepare new material about } B I P A \text { from other sources outside the demands } \\
\text { of the material in the syllabus }\end{array}$ & & & & \\
\hline 6 & $\begin{array}{l}\text { You have a complete source of learning materials as well as those exceeding the } \\
\text { material sources specified in the syllabus }\end{array}$ & & & & \\
\hline 7 & $\begin{array}{l}\text { You always clarify and confirm the new material that you have learned before during } \\
\text { the learning activity }\end{array}$ & & & & \\
\hline 8 & $\begin{array}{l}\text { You always try to pay attention to the material discussed in the class and ask for more } \\
\text { of the material discussed }\end{array}$ & & & & \\
\hline 9 & You always propose to discuss new materials that you hope can enrich your horizons & & & & \\
\hline 10 & You always try to find the latest reference sources in completing lecture assignments & & & & \\
\hline 11 & You always complete lecture assignments long before the assignment schedule & & & & \\
\hline 12 & You always realize and carry out learning activities under the ideals that you expect & & & & \\
\hline 13 & $\begin{array}{l}\text { You always manage your learning needs without having to have demanded from } \\
\text { others }\end{array}$ & & & & \\
\hline 14 & You always evaluate yourself and try to get the best results & & & & \\
\hline 15 & You always plan yourself in learning based on the results of self-evaluation & & & & \\
\hline 16 & You prefer lectures that challenge you to work hard than ordinary lectures & & & & \\
\hline 17 & $\begin{array}{l}\text { You prefer lectures with a lot of independent work than lectures that listen to a lot/ } \\
\text { lecture }\end{array}$ & & & & \\
\hline 18 & $\begin{array}{l}\text { You always feel dissatisfied with the learning experience you get from the discussion } \\
\text { and try to find other information yourself from other sources }\end{array}$ & & & & \\
\hline 19 & $\begin{array}{l}\text { You always associate conceptual information that you get in lectures with the facts } \\
\text { that occur in the field }\end{array}$ & & & & \\
\hline 20 & You always focus on your learning tasks based on the learning goals that you aspire to & & & & \\
\hline
\end{tabular}

